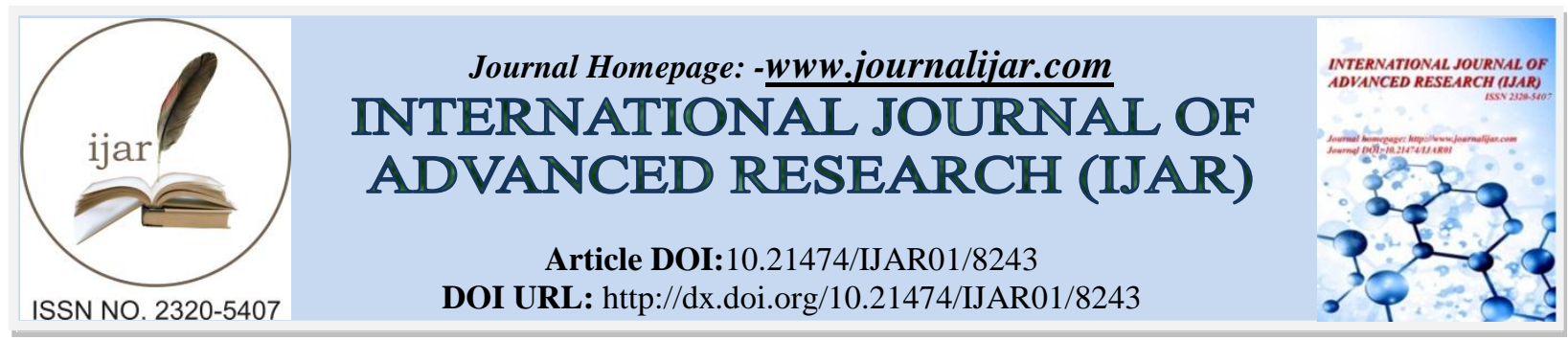

RESEARCH ARTICLE

\title{
PELANGGANECESSARY TO BUILD EMOTIONAL ATTACHMENT BETWEEN PATIENTS AND HOSPITAL?.
}

Tita Hariyanti, Harun Al Rasyid And Noor Annisa Susanto.

Hospital Management Program of Medical Faculty of Universitas Brawijaya.

\section{Manuscript Info}

\section{Manuscript History}

Received: 20 October 2018

Final Accepted: 22 November 2018

Published: December 2018

Keywords:-

emotional branding, switching intention, relationship, sensorial, experience, imagination, vision.

\section{Abstract}

Background:Consumers who has emotial attachment towards a product/service tends to consume that product/service repeatedly. This is known as emotional branding. Emotional attachment between a consumer and a product can prevent his/her "switching intention". Emotional brandingconsists of four essential variables, which are "relationship", "sensorial experience", "imagination", and "vision". Universitas Muhammadiyah Malang Hospital (RS UMM) has a marketing strategy that is closely related to the four previously mentioned variables. This emotional branding strategy has unintentionally been implemented by RS UMM.An increase in inpatient visits and several unstructured interviews results with the inpatients in RS UMM conveysome signs of potential brand switching, which requires RS UMM to maintain its consumers' loyalty by minimizing their "switching intention" to other hospitals. The purpose of this research is to find out the impact of "emotional branding"to "switching intention" of inpatient customers in RS UMM.

Methods:This research uses quantitative cross sectional method. The population is the whole inpatient customers with samples of 90 people taken via purposive sampling. The respondents is patients who are aged 17 years and above who are currently hospitalized for at least one day. yang sedang rawat inap minimal satu hari. Multiple linear regression is used to analyse these data.

Result:Based on unstructured interview with inpatient consumers, it can be concluded that they go through a pleasant sensorial experience through a spacious hospital design, giving a hotel-like ambience. They also experience "imagination" during their visits to the mosque in RS UMM with its oriental architecture design. Analysis results indicates that emotional branding (relationship, sensorial experience, imagination, and vision) influence greatly towards customers'"switching intention" ( $\mathrm{p}<0,05)$ simultaneously. While there is no significant impact of "relationship"and"sensorial experience" towards "switching intention" $(\mathrm{p}=0,839$ and $\mathrm{p}=0,997)$, "imagination"and"vision" contributes to customers" "switching intention" $(\mathrm{p}=0,023$ and $\mathrm{p}=0,005)$. Emotional branding contributes as many as $23,6 \%$, thus it can be said that variables within emotional branding is not a decisive factor on inpatient customers" "switching intention" in RS. Despite that, "emotional branding"can still be used as 
one of RS UMM's marketing strategy to increase and maintain its consumers.

Conclusion:Emotional branding (relationship, sensorial experience, imagination, and vision) is required in order to maintain the number of inpatient customers in RS UMM in order for them not to switch to other hospitals.

Copy Right, IJAR, 2018,. All rights reserved.

\section{Introduction:-}

\section{Pendahuluan:-}

Sebuah rumah sakit dikatakan berhasil apabila indikator efisiensi kinerjanya memenuhi standar. Kinerja pelayanan rumah sakit dapat dilihat dari beberapa indikator, salah satunya adalahbed occupancy rate (BOR). BOR rumah sakit yang ideal adalah sebesar 60-80\% (Depkes, 2005). Rumah Sakit Universitas Muhammadiyah Malang (RS UMM) merupakan salah satu rumah sakit swasta di Kabupaten Malang. Akses jalan masuk RS UMM melalui sebuah jalan yang merupakan perbatasan antara Kota dan Kabupaten Malang.

Laporan tahunan RS UMM menunjukkan BOR yang mengalami kenaikan(RS UMM, 2015).Gambaran kenaikan BOR RS UMM disajikan pada tabel 1.

Tabel 1:-BOR Pelayanan Rawat Inap RS UMM Tahun 2014 - 2016

\begin{tabular}{|l|l|l|}
\hline No & Tahun & BOR \\
\hline 1. & 2014 & $15 \%$ \\
\hline 2. & 2015 & $77 \%$ \\
\hline 3. & 2016 & $70 \%$ \\
\hline
\end{tabular}

Sumber : Laporan Tahunan RS UMM tahun 2014-2016

Tabel 1 menunjukkan adanya kenaikan BOR rawat inap yang cukup besar. Meskipun BOR tahun 2016 mengalami sedikit penurunan, namun masih dalam rentang BOR ideal. Pemanfaatan pelayanan rawat inap di RS UMM juga dipengaruhi oleh meningkatnya kunjungan pasien IGD dan rawat jalan. Gambaran kunjungan pasien di RS UMM berdasarkan jenis pelayanannya disajikan pada tabel 2 (RS UMM, 2015).

Tabel 2:-Kunjungan Pasien berdasarkan Pelayanan IGD, Rawat Jalan dan Rawat Inap pada Tahun 2014 - 2016

\begin{tabular}{|l|l|l|l|}
\hline \multirow{2}{*}{ Jenis Pelayanan } & Kunjungan Pasien & 2016 \\
\cline { 2 - 4 } & 2014 & 2015 & 22064 \\
\hline IGD & 124 & 14018 & 27050 \\
\hline Rawat Jalan & 3392 & 5375 & 7338 \\
\hline Rawat Inap & 1982 & 4853 & \\
\hline
\end{tabular}

Sumber:-Laporan Tahunan RS UMM tahun 2014-2016

Tabel 2 menggambarkan adanya peningkatan jumlah kunjungan di semua jenis pelayanan baik IGD, rawat jalan maupun rawat inap. Peningkatan jumlah kunjungan menunjukkan bahwa semakin banyak masyarakat yang memilih RS UMM untuk mendapatkan pelayanan kesehatan. Pengguna jasa yang merasakan manfaat menggunakan pelayanan rawat inap di rumah sakit akan merekomendasikan kepada orang lain untuk mendapatkan pelayanan kesehatan di rumah sakit tersebut (Rovitasari, 2013).

Dari hasil wawancara tidak terstruktur dengan beberapa pasien rawat inap di RS UMM pada bulan September-Oktober 2016,didapatkan data bahwa beberapa pasien yang sedang dirawat di RS UMM pernah dirawat di rumah sakit lain sebelumnya. Perilaku ini merupakan salah satu bentuk loyalitas pelanggan yang kurang terhadap suatu produk atau jasa sehingga melakukan perpindahan merek. Menurut Meka (2011) perilaku beralihnya seorang atau sekelompok pelanggan dari satu merek produk tertentu ke merek produk lainnya dikenal sebagai brand switching.Brand switching dipengaruhi oleh beberapa faktor antara lain adanya promosi, kualitas produk dan ketidakpuasan (Candra, 2014).

RS UMM bukanlah satu-satunya rumah sakit swasta di wilayah perbatasan Kabupaten Malang serta Kota Batu. Ada beberapa rumah sakit swasta yang letakkan tidak jauh dengan RS UMM. Melalui wawancara tidak terstruktur 
pelanggan yang menggunakan biaya mandiri merasa biaya perawatan di RS UMM lebih besar dibandingkan rumah sakit swasta lain yang letaknya tidak jauh dari RS UMM. Selain itu, RS UMM sendiri tergolong baru dibandingkan rumah sakit lain di wilayah tersebut, sehingga masih ada yang belum mengetahui tentang kualitas pelayanan maupun produk jasa yang diberikan oleh RS UMM. Kondisi ini akan berpengaruh pada perilaku brand switchingpelanggan di RS UMM, sehingga RS UMM mencoba melakukan berbagai strategi untuk menarik dan mempertahankan pelanggannya serta mencegah munculnya keinginan brand switching.Penelitian yang dilakukan oleh Keaveney bersama Parthasarathy (2001) menemukan perilaku brand switching dikarenakan sebelumnya sudah ada keinginan untuk berhenti menggunakan merek tertentu dan beralih menggunakan merek lainnya.

Keinginan pelanggan untuk berhenti atau beralih menggunakan merek lainnya menurut Bawanestri dalam Kurnia et al., (2014) dikenal sebagai switching intention. Switching intention adalah kecenderungan perilaku pelanggan yang berhubungkan dengan proses beralih dari satu merek produk atau jasa ke merek produk atau jasa lainnya. Besarnya niat beralih berkaitan erat dengan konsep keinginan untuk berperilaku yang dibangun dari perilaku sebelumnya terhadap produk dan jasa dari merek tertentu (Abdurrahman dan Suryadi, 2009).

Merek menurut Brakus dalam Rosenbaum (2015) adalah label yang menunjukkan kepemilikan suatu perusahaan. Merek merupakan aset tidak berwujud yang akan menghasilkan manfaat bagi perusahaan (Kapferer, 2012). Keseluruhan manfaat yang dirasakan pelanggan terdiri dari manfaat fungsional dan manfaat emosional (Kartajaya, 2007).

Manfaat fungsional berkaitan langsung dengan fungsi produk sedangkan manfaat emosional lebih kepada menciptakan hubungan emosi dan perasaan pelanggan dengan produk (Kartajaya, 2007). Beberapa peneliti berpendapat bahwa manfaat emosional mampu menutupi manfaat fungsional dari suatu merek produk (Lynch dan De Chernatony, 2004). Pelanggan yang terikat secara emosional lebih stabil mengeluarkan pengorbanan untuk mendapatkan pelayanan atau produk dari merek tersebut (Grisaffe danNguyen, 2011). Hubungan ini dikenal dengan istilah keterikatan emosional pelanggan kepada merek (Thomson et al., 2005). Strategi menciptakan suatu kondisi yang mampu menghubungan produk kepada pelanggan secara emosional dikenalkan oleh Gobe (2010) sebagai emotional branding.

Emotional branding menurut Gobe (2010) terdiri dari empat variabel penting yaitu hubungan (relationship), pengalaman pancaindera (sensorial experience), imajinasi (imagination) dan visi (vision). Berbagai strategi pemasaran yang dilakukan RS UMM berkaitan erat dengan empat variabel tersebut. Wawancara dengan salah satu wakil direktur dan staf bagian pemasaran, RS UMM berupaya menjalin hubungan (relationship) dengan pelanggan yang tercermin pada motto RS UMM yaitu "Layananku Pengabdianku". Wawancara tidak terstruktur dengan pelanggan rawat inap RS UMM menyampaikan bahwa mereka mendapatkan pengalaman pancaindera (sensorial experience) yang menyenangkan melalui desain rumah sakit yang luas dan lega serta memberikan kesan seperti di hotel. Mereka juga menikmati imajinasi (imagination) saat berada di masjid RS UMM dengan ciri khas arsitektur Tiongkok. Pengalaman yang dirasakan oleh pelanggan rawat inap RS UMM yang berkaitan erat dengan variabel emotional branding tersebut disampaikan pada saat wawancara sebagai salah satu alasan mereka untuk beralih (brand switching) mendapatkan pelayanan rawat inap di RS UMM. Hal ini didukung oleh penelitian Pawle dan Coper (2006) yang menemukan manfaat emosional lebih mempengaruhi keputusan memilih suatu produk atau layanan dari suatu merek tertentu dibandingkan manfaat fungsional yaitu sebesar $63 \%-85 \%$.

Strategi emotional branding yang tanpa disadari dilakukan oleh RS UMM merupakan salah satu metode pemasaran rumah sakit yang perlu dipertimbangkan. Peningkatan jumlah kunjungan rawat inap serta hasil wawancara tidak terstruktur dengan pelanggan rawat inap di RS UMM yang menyampaikan adanya perilaku brand switching perlu menjadi perhatian RS UMM untuk mempertahankan pelanggannya sehingga meminimalkan keinginan untuk pindah atau beralih (switching intention) ke rumah sakit lain. Latar belakang tersebut menjadi dasar untuk melakukan penelitian dengan judul pengaruh emotional branding(relationship, sensorial experience, imagination andvision) dan terhadap switchingintention pada pelayanan rawat inap di RS UMM.

\section{Metode:-}

Penelitian ini menggunakan desain penelitian kuantitatif observasional dengan pendekatan cross sectional. Pengaruh yang ingin diketahui dalam penelitian ini adalah pengaruh variabel bebas dari emotional branding (relationship, sensorial experience, imagination dan vision) terhadap variabel terikat yaitu perilaku switching intentionpelanggan layanan rawat inap di RS UMM. 
Lokasi penelitian di RS UMM pada bulan Maret-April 2017.Populasi meliputi seluruh pelanggan layanan rawat inap yang sedang dirawat di RS UMM, sedangkan sampel yang diambil adalah populasi yang memenuhi kriteria inklusi yaitu berusia lebih dari 17 tahun dan telah rawat inap minimal satu hari. Besar sampel yang dibutuhkan pada penelitian ini dihitung menggunakan rumus untuk populasi yang jumlahnya tidak diketahui dan didapatkan besar sampel sebanyak 90 orang.

Instrumen penelitian yang digunakan adalah kuesioner. Kuesioner terlebih dahulu dilakukan uji validitasnyadengan teknik Korelasi Pearson (Product Moment). Berdasarkan ringkasan hasil pengujian validitas instrumen penelitian diketahui bahwa semua nilai koefisien korelasi item dengan skor total $\left(\mathrm{r}_{\mathrm{iT}}\right)>$ nilai korelasi tabel $(0,361)$. Dengan demikian item pertanyaan/angket pada variabel Relationship, Sensorial Experience, Imagination, Vision, dan Switching Intention dinyatakan valid atau mampu mengukur variabel tersebut, sehingga dapat dipergunakan sebagai alat pengumpul data dalam penelitian ini.

Peneliti melakukan uji reliabilitasmenggunakan teknik Cronbach's Alpha.Pengujian reliabilitas menggunakan teknik Cronbach's Alpha. Kriteria pengujian menyatakan apabila koefisien Cronbach's Alpha $\geq 0.6$ berartiitem kuesionerdinyatakan reliabel atau konsisten dalam mengukur variabel yang diukurnya.Hasil pengujian reliabilitas instrumen penelitian menunjukkan semua nilai Cronbach's Alpha >0,6. Dengan demikian item pertanyaan/angket pada variabel Relationship, Sensorial Experience, Imagination, Vision, dan Switching Intention dinyatakan reliabel atau konsisten dalam mengukur variabel tersebut, sehingga dapat dipergunakan sebagai alat pengumpul data dalam penelitian ini. Metode analisa data yang digunakan dalam penelitian ini dengan analisa regresi linier berganda.

\section{Hasil:-}

Hasil penelitian menunjukkan bahwa responden yang terlibat dalam penelitian ini mempunyai karakteristik yang menarik. Mayoritas berjenis kelamin perempuan (68.9\%) dengan usia antara 21 - 40 tahun (50\%). Sebagian responden(47.8\%) memiliki latar belakang pendidikan tamat perguruan tinggidan berstatus mahasiswa (34.4\%). Responden rata-rata memiliki penghasilan kurang dari 1 juta(46.7\%). Hampir tiga perempatnyamempunyai pengalaman pertama kali rawat inap di RS UMM dan menggunakan BPJS sebagai sumber pembiayaannya.

Variabel yang diukur dalam penelitian ini adalah variabel emotional branding dan switching intention. Variabel emotional branding dapat diukur dari 4 indikator yaitu relationship, sensorial experience, imagination dan vision.

Indikator relationship mengukur hubunganyang mendalamantara rumah sakit dengan pasien dan keluarganya. Relationship juga dapat diukur dari rasa hormat pada jati diri pelanggan sehingga diharapkanakan memberikan pengalaman emosional yang mendalam (Gobe, 2005). Pengukuran relationship dalam emotional brandingdapat dilihat dari kenyamanan, jaminan, solusi, kepemahaman, kesejajaran, memberikan rasa hormat, tidak diabaikan, kesesuaian dengan gaya hidup pelanggan dan ketulusan. Pada penelitian ini didapatkan hasil yang sangat baik di seluruh item. Responden merasa bahwa relationship yang diberikan oleh rumah sakit membuat mereka betah di rumah sakit dan tidak ingin berpindah ke rumah sakit lain. Dari keseluruhan item, responden memberikan nilai tertinggi pada perasaan dihormati oleh seluruh petugas rumah sakit.

Sensorial experiencemerupakanaktivitas penciptaanmerekdengan cara memberikanrangsanganpancaindera kepadapelanggan. Indikatorsensorial experience yang diukur dalam penelitian ini antara lain : suara keras dari ruang lain, warna cat tembok, rasa makanan yang diberikan, desain dan aroma ruang rawat inap. Desain rawat inap merupakan alasan utama responden untuk memilih ulang RS UMM jika mereka ingin memanfaatkan pelayanannya lagi.

Imagination adalah upaya yang membuat emotional branding menjadi nyata. Pendekatan imajinatif merupakan ekspresi individualis dari sebuah rumah sakit yang harus ditampakkan seperti dari desain yang menunjukkan identitas dan kepribadian yang islami, suasana yang menciptakan kesan ramah danindah. Imagination juga diukur dari kepekaan, kesabaran, kejujuran dan komitmen dari seluruh petugas kesehatan yang memberikan pelayanan. Responden merasa petugas yang berada di RS UMM sangat ramah dan memberikan pelayanan yang terbaik.

Indikator terakhir adalah vision. Vision adalah faktor utama kesuksesan sebuah merek. Merek berkembang melalui daur hidup dan harus selalu berada dalam kondisi seimbang dengan cara memperbaharui merek secara terus menerus. Vision dalam emotional branding terkait brand focus, sense, dan brand presence management (BPM). Itembrand focusmengukur posisi merek RS UMM hanya berada di dalam benak pelanggan atau hingga ke dalam hati pelanggan 
(Kartajaya, 2005).Brand presence management adalah suatu cara untuk mendampingi pelanggan dalam melewati aktivitasnya (Gobe, 2005).Dari ketiga item, perasaan selalu teringat akan desain RS UMM mendapatkan nilai tertinggi.

Variabel terikat dalam penelitian ini adalah switching intention konsumen layanan rawat inap di Rumah Sakit Universitas Muhammadiyah Malang. Switching intention pada konsumen layanan rawat inap adalah keinginan atau niat konsumen untuk pindah dari RS UMM ke rumah lain pada saat mereka membutuhkan layanan rawat inap. Indikator ini diukur dari item keinginan berpindah ke rumah sakit lain dan keinginan untuk tetap dirawat di RS UMM. Hasilnya adalah responden tidak ingin berpindah ke rumah sakit lain dan tetap ingin dirawat di RS UMM jika kelak mereka sakit lagi.

Hasil pengujian pengaruh relationship, sensorial experience, imagination, dan vision terhadap switching intention dapat dilihat melalui tabel berikut :

Tabel 3:-Ringkasan Hasil Analisis Regresi Linier Berganda

\begin{tabular}{|c|c|c|c|c|c|}
\hline \multicolumn{2}{|l|}{ ariabel } & befisien & $\begin{array}{l}\text { andardized } \\
\text { beffisient }\end{array}$ & tatistic & $\mathrm{ob}$ \\
\hline \multicolumn{2}{|l|}{ onstanta } & 882 & & 118 & 000 \\
\hline \multicolumn{2}{|c|}{ lationship } & .043 & .026 & .204 & 839 \\
\hline \multicolumn{2}{|c|}{ nsorial Experience } & 00043 & 00043 & .004 & 997 \\
\hline \multicolumn{2}{|c|}{ agination } & .401 & .286 & .309 & 023 \\
\hline \multicolumn{2}{|c|}{ sion } & .359 & .309 & .905 & 005 \\
\hline tatistic & 7.877 & $o b$ & 0.000 & & \\
\hline squared & 0.270 & $\begin{array}{l}\text { dj. R- } \\
\text { uared }\end{array}$ & 0.236 & & \\
\hline
\end{tabular}

Sumber:-data primer diolah, 2017

Besarnya kontribusi relationship, sensorial experience, imagination, dan vision terhadap switching intention dapat diketahui melalui koefisien determinasinya $\left(\mathrm{Adj} \mathrm{R}^{2}\right.$ ) yaitu sebesar 0.236 . Hal ini berarti kontribusi relationship, sensorial experience, imagination, dan vision terhadap switching intention sebesar $23.6 \%$, sedangkan sisanya sebesar $76.4 \%$ merupakan kontribusi dari variabel lain yang tidak dibahas dalam penelitian ini.

Pengujian hipotesis secara simultan menghasilkan nilai $\mathrm{F}_{\text {hitung }}$ sebesar 7.877 dengan probabilitas sebesar 0.000 . <level of significance $(\alpha=5 \%)$. Hal tersebut menunjukkan terdapat pengaruh yang signifikan secara simultan (bersama-sama) dari varibel dalam emotional branding (relationship, sensorial experience, imagination, dan vision)terhadap switching intention.

Pengujian hipotesis secara parsial relationship menghasilkan nilai t hitung sebesar - 0.204 dengan probabilitas sebesar 0.839 dan koefisien relationship sebesar -0.043 mengindikasikan bahwa relationshipberpengaruh negatif terhadap switching intention. Artinya, semakin baik relationshipmaka cenderung dapat menurunkan switching intention. Namun penurunan tersebut tidak signifikan.

Pengujian hipotesis secara parsial sensorial experience menghasilkan nilai t hitung sebesar - 0.004 dengan probabilitas sebesar 0.997 dan koefisien sensorial experience sebesar 0.00043 mengindikasikan bahwa sensorial experience berpengaruh positif terhadap switching intention. Artinya, semakin baik sensorial experience maka cenderung dapat meningkatkanswitching intention. Namun peningkatan tersebut tidak signifikan.

Pengujian hipotesis secara parsial imagination menghasilkan nilai t hitung sebesar -2.309 dengan probabilitas sebesar 0.023 dan koefisien imagination sebesar -0.401 mengindikasikan bahwa imagination berpengaruh negatif terhadap switching intention. Ini dapat diartikan semakin baik imagination maka cenderung dapat menurunkan switching intention.

Pengujian hipotesis secara parsial vision menghasilkan nilai $t$ hitung sebesar -2.905 dengan probabilitas sebesar 0.005dan koefisien vision sebesar -0.359 mengindikasikan bahwa vision berpengaruh negatif terhadap switching intention. Hal ini menunjukkan semakin baik vision maka cenderung dapat menurunkan switching intention. 
Hasil estimasi yang tertera pada tabel di atas dapat diketahui bahwa variabel yang memiliki koefisien standardisasi terbesar adalah variabel vision sebesar 0.309. Dengan demikian vision memiliki pengaruh yang paling dominan terhadap switching intention.

\section{Diskusi:-}

Responden dalam penelitian ini adalah pasien yang sedang rawat inap di Rumah Sakit Universitas Muhammadiyah Malang (RS UMM) dan telah merasakan pelayanan rawat inap minimal satu hari. Pasien rawat inap pada semua kelas perawatan diperkenankan menjadi responden kecuali pasien ruang VIP (very important person) dan ruang VVIP (very very important person).

Jenis kelamin perempuan mendominasi sebagian besar dari responden. Menurut Magnadi dan Indriani (2013) bahwa perempuan memegang kendali terhadap lebih dari 80\% keuangan keluarga. Ini dikarenakan mayoritas perempuan melakukan pembelian terhadap keluarganya cukup besar, mulai dari suami, orang tua dan anak-anak. Perempuan sendiri lebih banyak memanfaatkan pelayanan kesehatan dibandingkan laki-laki (Bertakis et al.,2000). Hal ini didukung oleh penelitian Relliyani (2000) dalam Tasya dan Andriany (2016) yang menemukan bahwa salah satu karakteristik pasien yang mempengaruhi pemanfaatan pelayanan kesehatan adalah jenis kelamin. Hal ini sejalan dengan Kartajaya (2009) yang mengungkapkan adanya target pasar potensial baru yang disebut sebagai Threenew wave ready costumer, yaitu kaum muda (youth), perempuan (woman) dan pengguna internet (netizen). Kondisi perempuan sebagai pemberi pengaruh dan pembuat keputusan tersebut menyebabkan perempuan lebih banyak berperan penting, sehingga RS UMM perlu mempertimbangkan hal tersebut dalam strategi pemasaran.

Strategi emotional branding yang dilakukan oleh RS UMM berusaha menghubungkan antara produk dan konsumennya secara emosional. Ratnasari dan Suleeman (2017) menemukan ada perbedaan dalam mengelola emosi antara perempuan dengan laki-laki, namun menurut Kartajaya et al., (2004) saat ini masyarakat baik laki-laki maupun perempuan semakin emosional seperti penduduk Venus (Venusian). Keadaan dunia venus menggambarkan bahwa lakilaki memiliki orientasi berpikir layaknya perempuan "woman-oriented man". Laki-laki yang dimaksud disini adalah kemampuan berpikir laki-laki yang lebih mampu menunjukkan perasaannya secara emosional sehingga pemasaran di dunia venus perlu menjadi perhatian dari pemasar.

Pemasar di "Venus" harus memperhatikan prinsip-prinsip marketing in venus. Kartajaya (2004) menyampaikan prinsip tersebut meliputi : menggunakan insting dalam membaca perubahan pasar, proaktif, mengutamakan feel, mengedepankan empati dalam layanan, bisa menyentuh hati pelanggan, tidak berbohong/memegang janji kepada pelanggan, serta mampu memberikan pengalaman yang berkesan kepada konsumennya.

Responden sebagian besar berusia 21-40 tahun. Menurut kriteria WHO kelompok usia ini termasuk dalam pemuda (youth). Kelompok usia ini juga merupakan kelompok usia produktif dengan beban kerja tinggi sehingga beresiko terhadap stres kerja. Menurut penelitian Fitri (2013) bahwa faktor yang berhubungan dengan stres kerja adalah usia dan masa kerja. Kondisi ini dapat menyebabkan kelompok usia tersebut mulai memanfaatkan pelayanan kesehatan. Penelitian Gaol (2013) dan Rovitasari (2013) yang mengemukakan bahwa pencarian pengobatan dan pengguna jasa pelayanan rawat inap paling banyak pada rentang usia 18-40 tahun. Sejalan dengan pernyataan Notoadmojo (2005) bahwa salah satu faktor yang mempengaruhi pemanfaatan pelayanan kesehatan adalah usia. Hal ini sesuai dengan penelitian yang dilakukan oleh Logen dan Balqis (2015) yang menemukan ada hubungan antara usia dan pemanfaatan pelayanan kesehatan, namun bertolak belakang dengan penelitian Sampeluna dan Hamzah (2013) yang menyampaikan bahwa usia dan pemanfaatan pelayanan kesehatan tidak berhubungan.

Rentang usia yang termasuk dalam kelompok produktif juga berperan aktif sebagai pengguna internet (netizen). Kartajaya (2009) mengemukakan bahwa dengan perkembangan teknologi membuat pengguna jasa lebih mudah mencari informasi dan membandingkan antara penyedia jasa satu dengan lainnya melalui media internet. Penelitian yang dilakukan oleh Magnadi dan Indriani (2013) menemukan bahwa 40\% dari pemuda (youth) yang berusia 14-35 tahun cenderung berani menggunakan produk baru. Kecenderungan ini dapat meningkatkan resiko dari pengguna jasa untuk memanfaatkan fasilitas pelayanan lain yang mampu memberikan pelayanan yang sama (switching intention).

Separuh dari responden berpendidikan hingga tamat perguruan tinggi baik diploma, sarjana maupun paska sarjana. Penelitian Napirah, dkk (2016) menemukan bahwa pemanfaatan pelayanan kesehatan sebesar 82,6\% dipengaruhi oleh pendidikan seseorang. Menurut Notoatmodjo (2007) tingkat pendidikan seseorang juga berpengarug terhadap informasi yang diterima, semakin tinggi tingkat pendidikan maka semakin baik pemahamannya. RS UMM berupaya 
menyampaikan informasi melalui berbagai media seperti brosur, leafleat dan website. Selain itu RS UMM juga rutin melakukan berbagai kegiatan di masyarakat antara lain seminar, workshop, dan bakti sosial. Melalui kegiatan tersebut diharapkan masyarakat bisa mendapatkan informasi dan mempengaruhi pemahaman masyarakat mengenai pelayanan di RS UMM. Melalui pemahaman tersebut diharapkan dapat berpengaruh terhadap keputusan masyarakat dalam memilih rumah sakit.

RS UMM saat ini telah bekerja sama dengan Badan Penyelenggaran Jaminan Sosial (BPJS) kesehatan dan 14 asuransi lainnya. Sumber pembiayaan responden yang terbesar adalah menggunakan BPJS kesehatan. Pembiayaan dengan BPJS berkaitan erat dengan penghasilan dan tingkat pendidikan seseorang. Hal ini sesuai dengan penelitian yang dilakukan oleh Binti (2016) yang mengemukakan bahwa faktor-faktor yang mempengaruhi seseorang dengan keikutsertaan dalam program BPJS kesehatan adalah pengetahuan, sikap, informasi yang diperoleh, dukungan keluarga dan penghasilan. Upaya dari RS UMM bekerja sama dengan beragam asuransi menunjukkan bahwa RS UMM berusaha untuk menjangkau seluruh lapisan masyarakat.

Hampir separuh dari responden memiliki penghasilan kurang dari Rp.1.000.000,- setiap bulannya. Hal ini dikarenakan mayoritas responden tidak memiliki penghasilan sendiri, melainkan penghasilan responden berasal dari orang lain seperti orang tua atau suami. Pernyataan ini sesuai dengan latar belakang pekerjaan responden yang sebagian besar merupakan mahasiswa dan ibu rumah tangga.

Hasil pengujian hipotesis membuktikan bahwa seluruh variabel di dalam emotional branding yaitu relationship, sensorial experience, imagination, dan vision secara bersama-sama (simultan) berpengaruh terhadap switching intention.Switching intention merupakan kecenderungan perilaku konsumen yang berhubungan dengan keinginan beralih dari satu merek produk atau jasa ke merek produk atau jasa lainnya. Besarnya switching intention berkaitan erat dengan konsep keinginan untuk berperilaku yang dibangun dari perilaku sebelumnya dan sikap konsumen terhadap produk atau jasa dari merek tertentu (Abdurrahman dan Suryadi, 2009). Perilaku switching intention ini adalah salah satu bentuk kurangnya loyalitas konsumen terhadap merek produk atau jasa tertentu. Strategi pemasaran yang berbeda diperlukan untuk mempertahankan loyalitas konsumen.

Gobe (2010) memperkenalkan salah satu strategi pemasaran baru yaitu emotional branding. Emotional branding adalah suatu upaya untuk menciptakan kondisi yang mampu menghubungkan antara produk dengan konsumen secara emosional. Menurut Grisaffe dan Nguyen (2011) konsumen yang terikat secara emosional lebih stabil mengeluarkan pengorbanan untuk mendapatkan pelayanan atau produk dari merek tersebut.Konsumen yang stabil diharapkan dapat menjadi konsumen yang loyal sehingga tidak ada keinginan pindah (switching intention) ke rumah sakit lain. Hal ini didukung oleh penelitian Devina dan Andreani (2015) yang menemukan bahwa keseluruhan variabel dalam emotional branding (relationship, sensorial experience, imagination, dan vision) secara bersama-sama berpengaruh signifikan terhadap loyalitas. Penerapan strategi emotional branding menurut Adona dan Zerwen (2010) dapat mencegah suatu penyedia layanan dianggap melakukan pemaksaan, namun membuat konsumen tidak mampu menolak tawaran yang diberikan oleh pemasar. Keterlibatan emosi konsumen selalu menjadi alat yang lebih kuat dalam strategi untuk membuat suatu merek menjadi sukses (Pandey, 2006). De Chernatony (2010) mempertegas dengan mengemukakan sebuah merek yang bernilai emosional tidak hanya mampu menarik sekelompok konsumen, tetapi juga menjadikannya konsumen yang berkelanjutan dalam jangka waktu panjang.

Hasil model regresi linier ini dapat digunakan oleh RS UMM untuk melihat perkembangan switching intention dari konsumen layanan rawat inap. Artinya, penerapan strategi pemasaran dengan emotional branding yang dilakukan oleh RS UMM diharapkan dapat menekan keinginan beralih (switching intention) dari konsumen rawat inapnya, sehingga konsumen tersebut menjadi loyal.

Emotional branding memberikan konstribusi sebesar 23,6\% terhadap switching intention, sedangkan 76,4\% merupakan kontribusi dari variabel lain yang tidak diamati dalam penelitian ini. Menurut penelitian yang dilakukan oleh Nelloh dan Liem (2012) switching intention sebesar 67,74\% dapat dijelaskan oleh variabel kualitas layanan. Kontribusi dari keseluruhan variabel emotional branding sebesar 23,6\% dapat dikatakan bahwa variabel dalam emotional branding bukanlah faktor penentu utama dari switching intentionpelanggan rawat inap di RS UMM. Namun emotional branding tetap dapat digunakan sebagai salah satu strategi pemasaran bagi RS UMM untuk meningkatkan dan mempertahankan pelanggannya. 
Hal yang berbeda ditemukan pada variabel sensorial experience, Pengujian hipotesis secara parsial serta nilai koefisien yang sangat kecil menunjukkan tidak terdapat pengaruh yang bermakna darisensorial experience terhadap switching intention dengan arah yang positif. Artinya, semakin baik sensorial experience maka cenderung dapat meningkatkanswitching intention, namun peningkatan tersebut tidak bermakna. Peningkatan switching intention merupakan bentuk loyalitas konsumen yang mulai berkurang, temuan ini bertolak belakang dengan penelitian Jatmiko dan Andharini (2012) bahwa sensory experience berpengaruh terhadap loyalitas.

Wawancara tidak terstruktur dengan responden diketahui bahwa keseluruhan pernyataan dalam variabel sensorial experience merupakan hal yang biasa di rumah sakit. Responden menyampaikan setuju suara pengunjung yang terlalu ramai dapat mengganggu istirahat dari pasien, namun mereka dapat memaklumi karena suara tersebut terdengar di jam kunjungan. Begitu pula dengan desain ruang rawat inap, mereka mengatakan desain ruang rawat inap RS UMM tidak jauh berbeda rumah sakit lain. Selain itu responden juga menyampaikan menyukai makanan di RS UMM, namun bagi mereka makanan yang enak tetaplah makanan di rumah. Hal serupa disampaikan pada aroma ruang rawat inap, bagi responden biasa saja apabila pada saat dipel tercium aroma karbol yang sudah menjadi ciri khas bagi rumah sakit.

Pernyataan yang disampaikan oleh responden mengenai variabel sensorial experience sesuai dengan konsep classical conditioning. Classical conditioning berpendapat bahwa manusia merupakan salah satu organisme hidup yang dapat diberikan stimulus secara berulang-ulang, sehingga manusia akan memberikan respon yang sama pada stimulus tersebut. Informasi semacam ini akan disimpan di alam bawah sadar (Ferrinadewi, 2008).

Variabel emotional branding yang dijabarkan dalam lima pernyataan berkaitan erat dengan panca indera. Pernyataan tersebut meliputi suara yang tidak mengganggu berhubungan dengan indera pendengaran, warna ruang rawat inap yang berkaitan dengan indera penglihatan, rasa makanan melalui indera pengecap, bentuk desain ruang rawat inap yang berkaitan dengan indera peraba dan aroma ruang rawat inap yang mengesankan indera pembau. Penelitian yang dilakukan oleh Wenno (2013) menemukan bahwa pengalaman yang berkaitan dengan panca indera yang mengesankan dapat membangkitkan perasaan emosional yang positif dari konsumen.

Keseluruhan pernyataan yang ada dalam variabel sensorial experience mencerminkan tampilan fisik dari RS UMM. Hal tersebut ternyata bukanlah hal yang utama dibutuhkan oleh konsumen rawat inap di RS UMM. Keseluruhan variabel dalam emotional branding harus dijalankan secara bersama-sama, sehingga sensorial experience tetap harus dipertahankan dan ditingkatkan dengan harapan dapat mengurangi switching intention sehingga konsumen menjadi loyal.

Pada variabel imagination secara parsial terdapat pengaruh yang bermakna terhadap switching intention dengan arah negatif. Dari hasil pengujian dapat dikatakan semakin baik imagination maka secara bermakna cenderung dapat menurunkan switching intention.Imagination sebagian variabel dalam emotional branding tidak terlepas dari proses persepsi untuk mempengaruhi konsumen (Ferrinadewi, 2008). Proses persepsi adalah suatu proses diterimanya stimulus oleh seseorang melalui panca indera sehingga individu menyadari apa yang dilihat, didengar ataupun stimulus lainnya yang diterima melalui panca inderanya (walgito, 2004).

Upaya RS UMM dalam menerapkan variabel imagination nampak pada desainnya yang menunjukkan identitas Muhammadiyah dan islami. Sebagian besar responden setuju bahwa desain RS UMM menunjukkan identitas Muhammadiyah dan islami. Melalui wawancara tidak terstruktur responden menyampaikan bahwa nuansa Muhammadiyah dan islami membuat responden merasa nyaman karena pasti akan dilayani oleh petugas kesehatan yang memiliki keyakinan yang sama dengan responden. Hal ini didukung oleh penelitian Bawono (2016) yang menemukan aspek pelayanan spiritual dan religius mempengaruhi keputusan pasien dalam berobat.

RS UMM juga berupaya menciptakan suasana pelayanan sesuai dengan harapan dari konsumen. Suteja (2007) menyebutkan bahwa konsumen menginginkan pelayanan yang ramah, kejujuran mengenai produk yang mereka beli, pelayanan yang cepat dan tepat, sehingga dapat dikatakan konsumen menginginkan pelayanan yang terbaik. Suasana pelayanan yang sudah diciptakan oleh RS UMM sebagai wujud dari variabel imagination dan dibuktikan berpengaruh secara bermakna terhadap switching intention hendaknya terus dipertahankan. Hal ini dikarena masih ada sebagian responden yang tidak setuju terhadap pernyataan dalam variabel imagination. Darihasil wawancara tidak terstruktur dengan responden diketahui untuk pelayanan pasien pulang masih membutuhkan waktu yang cukup lama. hal berbeda mengenai kesan ramah dan sabar. Responden menyebutkan bahwa hampir keseluruhan petugas yang ada di ruang rawat inap RS UMM bersikap ramah dan sabar terhadap konsumen. Pernyataan mengenai fasilitas dan pelayanan dari beberapa responden menginformasikan bahwa hal tersebut tidak disampaikan terlebih dahulu sebelum mereka rawat 
inap. Hal - hal tersebut sebaiknya ditingkatkan oleh RS UMM. Hal ini didukung oleh hasil penelitian yang menemukan variabel imagination berpengaruh secara bermakna terhadap switching intention. Harapannya adalah apabila upaya dari RS UMM untuk meningkatkan imagination akan semakin menurunkan switching intention dari konsumen rawat inap RS UMM, sehingga mereka menjadi pasien yang loyal.

Hal yang serupa juga terdapat pada variabel vision. Pengujian hipotesis secara parsial pada variabel vision menghasilkan pengaruh yang bermaknadari vision terhadap switching intention dengan arah yang negatif. Hal ini berarti semakin baik vision maka secara bermakna cenderung dapat menurunkan switching intention.Vision adalah salah satu konsep dasar dari emotional branding yang keempat. Vision merupakan faktor kesuksesan dari suatu merek dalam jangka panjang. Menurut Dunn (2004) vision adalah yang ada di sekitar bahkan melewati batasan untuk mencapai tujuan besar yang mampu melibatkan seluruh karyawan sehingga membuat merek mereka menjadi besar. Vision yang meyakinkan, terarah pada tujuan, dan dikomunikasikan secara efektif akan berdampak kuat dan positif pada tujuan yang ingin dicapai (Christenson dan Walker, 2008).

Penerapan vision di RS UMM dapat dikatakan berhasil. Hal ini terungkap dalam pernyataan yang disetujui oleh mayoritas responden bahwa RS UMM adalah yang terlintas pertama kali saat membutuhkan pelayanan rawat inap. Selain itu, setelah responden menyampaikan bahwa RS UMM yang pertama kali terpikirkan pada saat membutuhkan pelayanan rawat inap mereka yang mendapatkan pengalaman menyenangkan di RS UMM akan selalu teringat dengan RS UMM setiap kali orang lain membutuhkan pelayanan kesehatan. Hal ini berarti responden yang terikat secara emosi dengan RS UMM dengan senang hati merekomendasikan RS UMM kepada orang lain.

Keberhasilan vision menurut Lemberg (2008) harus memiliki poin sebagai berikut : (1) vision harus unik, (2) vision harus sederhana dan mudah dipahami, (3) vision tertuang dalam bentuk produk atau layanannya, (4) vision dari suatu penyedia layanan sedapat mungkin belum ada di pasaran, (5) vision membutuhkan waktu untuk mencapainya (6) vision memerlukan kegigihan terus menerus, kepuasan terhadap satu keberhasilan kecil akan mengurangi inovasi vision. Vision juga erat kaitannya dengan komitmen terhadap kualitas. Penelitian Fajar dan Hasibuan (2016) menemukan bahwa kualitas pelayanan berpengaruh positif terhadap kepuasan dan loyalitas pasien. Pasien yang loyal akan menjamin keberlangsungan dari RS UMM secara terus menerus, seperti yang dinyatakan dalam variabel vision. Oleh karena itu RS UMM selain tetap melakukan berbagai strategi pemasaran juga harus meningkatkan kualitas pelayanannya secara terus menerus.

Keempat variabel dalam emotional branding yang dominan berpegaruh adalah varibel vision. Ini dilihat dari standardized coefficient dari variabel vision paling besar jika dibandingkan variabel lainnya yaitu sebesar negatif 0.309. Vision dalam emotional branding berkaitan dengan daur hidup dari suatu merek. Merek harus diperbaharui secara terus menerus dan dipilih setiap hari. Dari pernyataan dalam variabel vision responden menyampaikan setuju bahwa mereka merasa RS UMM yang terlintas pertama kali dalam pikiran mereka saat mereka membutuhkan pelayanan rawat inap. Hal ini dikarenakan beberapa penyebab. Dari wawancara tidak terstruktur diketahui salah satu penyebab terlintasnya RS UMM yang pertama kali adalah karena jarak dari rumah dan RS UMM paling dekat dibandingkan dengan rumah sakit lain. Namun ada juga respoden yang berasal dari lokasi yang tidak satu kecamatan dengan RS UMM menyampaikan bahwa mereka terlintas pertama kali ke RS UMM karena fasilitas yang diberikan lebih baik dibandingkan rumah sakit lain. Selain itu ada pula responden mengatakan bahwa mereka terlintas pertama kali ke RS UMM karena sudah menjadi kebiasan sejak rawat jalan sudah di RS UMM dan ditangani oleh dokter di poli rawat jalan RS UMM sehingga pada saat mereka akan rawat inap tidak memikirkan rumah sakit lain dengan harapan dokter yang menangani sudah mengerti riwayat penyakit mereka.

Pernyataan dalam variabel vision yang paling menonjol adalah pada perasaan senang dengan desain RS UMM. Sebanyak 65.6\% responden setuju mereka merasa senang dengan desain RS UMM. Responden menyampaikan mereka menyukai desain bangunan yang tidak terkesan seperti rumah sakit pada umumnya. Bangunannya luas dan lega sehingga tidak terkesan gelap atau menakutkan. Bahkan ada beberapa responden yang menyampaikan RS UMM seperti hotel. Mayoritas responden menyatakan mereka selalu teringat dengan RS UMM setiap kali ada orang lain yang membutuhkan pelayanan kesehatan. Sehingga sebagian dari responden menyampaikan akan merekomendasikan RS UMM kepada orang lain.

Hasil penelitian menunjukkan bahwa keseluruhan variabel dalam emotional branding (relationship, sensorial experience, imagination dan vision) secara bersama-sama berpengaruh terhadap switching intention konsumen rawat 
inap di RS UMM. Secara parsial dua dari keempat variabel dalam emotional branding yaitu variabel imagination dan vision berpengaruh terhadap switching intention konsumen rawat inap di RS UMM.

Berdasarkan temuan dalam penelitian ini, RS UMM dapat menerapkan emotional branding secara utuh, dengan harapan dapat menekan switching intention dari konsumen rawat inap sehingga menjadi konsumen yang loyal terhadap RS UMM. Keberhasilan switching intentionini tidak hanya melibatkan bagian tertentu di dalam RS UMM, tetapi seluruh personil dalam RS UMM baik manajemen maupun pelayanan berperan aktif dalam menerapkan strategi emotional branding. Kontribusi emotional branding terhadap switching intention meskipun hanya 23,6\% tetap perlu mendapat perhatian. Beberapa hal yang dapat dilakukan oleh RS UMM untuk mewujudkan strategi emotional branding, antara lain : pelatihan pelayanan prima secara rutin, optimalisasi bimbingan kerohanian dan penerapan prinsip-prinsip dalam mom strategic.

Strategi emotional branding khususnya terkait varibel vision sebagai variabel yang paling berpengaruh terhadap switching intention konsumen rawat inap di RS UMM erat kaitannya dengan komitmen seluruh pihak dalam RS UMM terhadap kualitas. Penerapan strategi ini tidak hanya didukung oleh fasilitas fisik dan layanan yang dapat dirasakan oleh panca indera sesuai dengan kebutuhan konsumen, melainkan harus melibatkan emosi dari konsumen. Setiap petugas yang memberikan pelayanan di rumah sakit hendaknya dapat memahami emosi konsumen dan memperlakukan konsumen dengan sabar. Menurut Djati (2016) Hal ini akan tercapai apabila petugas mampu bersikap carring terhadap konsumen dengan memperlihatkan kata-kata yang lemah lembut, sikap ramah, memberikan harapan serta rasa aman bagi konsumen.

Kemampuan petugas besikap carring sehingga dapat memahami kebutuhan dan keinginan pasien merupakan salah satu penerapan strategi emotional branding yang mencerminkan pelayanan prima. Selain itu, untuk dapat memberikan pelayanan prima menurut Safarino dalam Hadjam (2001) petugas di rumah sakit juga perlu mengembangkan beberapa keterampilan seperti : komunikasi efektif, kemampuan mendengarkan dan empati. Hal ini senada dengan penelitian Mulyani (2008) bahwa ada hubungan yang bermakna antara komunikasi intrapersonal dengan kesadaran emosi dan empati. Seluruh petugas di RS UMM baik itu petugas kesehatan, petugas keamanan, administrasi, petugas kebersihan sebaiknya memiliki keterampilan dan kemampuan ini agar strategi emotional branding berhasil.

Kemampuan ini tidak serta merta dimiliki oleh seluruh petugas yang ada di RS UMM. Membutuhkan waktu dan proses agar seluruh petugas memiliki kemampuan dan keterampilan tersebut. Keterampilan tersebut dapat diasah melalui pelatihan rutin yang dilakukan secara konsisten, sehingga RS UMM perlu melakukan pelatihan pelayanan prima secara terus menerus kepada seluruh karyawannya. Salmah (2012) mengemukakan program pelatihan dapat meningkatkan keterampilan, kemampuan dan kompetensi karyawan. Pernyataan ini didukung oleh Graha (2006) yang mengemukakan pelatihan berpengaruh terhadap peningkatan kemampuan yang akan berdampak pada kinerja karyawan.

Variabel imagination memberikan pengaruh yang bermakna terhadap switching intention konsumen rawat inap di RS UMM. Keseluruhan responden mayoritas setuju terhadap item pernyataan dalam varibel imagination, namun pada analisis deskriptif responden yang menyampaikan setuju terhadap item bahwa RS UMM menunjukkan identitas Muhammadiyah dan kepribadian islami lebih sedikit dibandingkan item pernyataan lainnya dalam imagination.

Hasil ini dapat digunakan oleh RS UMM untuk meningkatkan pelayanan terkait kepribadian islami sebagai bagian dari identitas Muhammadiyah. Wujud pelayanan tersebut dapat berupa pelayanan kerohanian yang tidak hanya ditujukan kepada salah satu keyakinan tertentu, tetapi pelayanan kerohanian merupakan hak bagi seluruh pasien di RS UMM. Menurut Chabibah (2011) pelayanan bimbingan rohani dapat mengurangi rasa cemas, gelisah dan putus asa yang sering kali dirasakan oleh pasien yang sedang sakit. Didukung oleh pernyataan wijayanti (2017) dalam penelitiannya bahwa pelayanan bimbingan rohani menunjang kesembuhan pada pasien rawat inap. Pelayanan kerohanian yang ada di RS UMM saat ini sudah ada dalam bentuk pelayanan merawat jenazah. Hal ini perlu ditingkatkan melalui optimalisasi pelayanan kerohanian seperti :-

1. Bimbingan dan motivasi ibadah pada saat sakit yang ditujukan tidak hanya untuk pasien tetapi juga keluarga yang menunggu atau berkunjung. Bentuk layanan dapat berupa pendampingan tata cara ibadah sholat pada saat sakit. Layanan ini membutuhkan kerja sama dengan ustadz/ustadzah atau pengurus masjid terdekat. Ustadz/ustadzah sebagai pendamping bisa datang ke ruang rawat inap untuk memberikan motivasi dan menjelaskan tata cara sholat saat sakit.

2. Ceramah singkat pada pagi hari selama 5-10 menit melalui pengeras suara di ruang rawat inap RS UMM.

3. Pendampingan bagi pasien yang terminal sesuai dengan keyakinan pasien. 
Strategi emotional branding secara menyeluruh berupaya menguhubungkan suatu produk dengan konsumen secara emosional (Gobe, 2010). Perempuan cenderung memiliki emosional yang berbeda dibandingkan laki-laki (Ratnasari dan Suleeman, 2017). Mayoritas responden adalah perempuan, Magnadi dan Indriani (2013) mengemukakan mayoritas perempuan memegang kendali terhadap keuangan keluarga. Dunia yang semakin venus membuat konsumen termasuk laki-laki berpikir dengan orientasi perempuan. Kondisi ini menyebabkan perempuan berperang penting dalam memberikan pengaruh dan pembuat keputusan dalam keluarga, sehingga Mom strategic yang diungkapan oleh Kartajaya (2005) dapat digunakan oleh pemasar sebagai strategi menghadapi dunia yang semakin venus. Beberapa prinsip dalam mom strategic yaitu;-

1. Memposisikan merek sebagai merek keluarga, misal dengan menyediakan pelayanan dengan paket keluarga. Pelayanan tersebut dapat berupa paket layanan medical cek up untuk keluarga (paket suami/istri, paket suami/istri/anak). Paket layanan dapat disesuikan dengan kebutuhan keluarga.

2. Menyentuh hati ibu, di era venus yang utama adalah memperebutkan hati pelanggan. Salah satu cara untuk merebut hati ibu adalah melalui anak. Ibu akan selalu mendedikasikan kebaikan bagi anaknya (Kartajaya, 2005). Wujud pelayanan yang dapat diberikan oleh RS UMM misal pelayanan pemeriksaan gigi anak secara gratis pada anak pasien yang sedang rawat inap di RS UMM.

3. Memberikan produk sesuai dengan yang dijanjikan. Misal, RS UMM menyediakan pemeriksaan gigi gratis bagi anak pasien yang sedang di rawat inap di RS UMM. Perlu dibuat jadwal pemeriksaan tersebut, misal pelayanan pemeriksaan gigi gratis bagi anak pasien rawat inap dilakukan pada pukul 10.00-12.00 setiap hari senin - sabtu. Pada jam pelayanan tersebut RS UMM harus berkomitmen menjamin pemeriksaan gratis dilayani. Menurut Kartajaya (2005) dalam masyarakat venus apabila suatu layanan tidak sesuai dengan janjinya maka merek layanan tersebut hanya tinggal 5\% saja.

Menghargai waktu yang dimiliki kosumen. Membuat konsumen merasa nyaman, berikan konsumen layanan yang praktis dan menghemat waktu konsumen. Pemberian layanan pemeriksaan gigi gratis bagi anak pasien yang sedang di rawat inap di RS UMM merupakan salah satu bentuk pelayanan yang dapat menghemat waktu konsumen dikarenakan pada saat orang tua sedang di rawat inap, anaknya sekaligus dapat melakukan pemeriksaan gigi.

Penelitian ini memiliki beberapa keterbatasan, antara lain adalah peneliti tidak menyebarkan kuesioner dan melakukan wawancara kepada pasien yang dirawat inap di ruangan VIP dan VVIP. Hal ini menjadi keterbatasan peneliti sehingga sumber data penelitian belum bisa mewakili seluruh kelas perawatan yang tersedia.

Keterbatasan lain dalam penelitian ini adalah kriteria inklusi yang menyebutkan pemilihan pasien yang telah mendapatkan perawatan minimal 1 hari. Pasien yang medapatkan perawatan 1 hari belum tentu telah merasakan semua pengalaman secara emotional selama dirawat inap. Misalnya masih ada pasien yang belum bertemu dengan dokter penanggung jawabnya. Kemudian masih ada pasien yang belum melihat RS UMM secara keseluruhan. Selain itu pasien yang baru 1 hari dirawat inap mungkin saja masih berkonsentrasi pada sakitnya. Keterbatasan ini menyebabkan peneliti menyarankan untuk penelitian selanjutnya sebaiknya mengambil sampel yang telah dirawat inap minimal 2 hari atau sudah pernah dirawat inap sebelumnya di RS UMM.

Keterbatasan berikutnya adalah pada penelitian yang bersifat kuantitatif umumnya menggunakan nilai tertinggi sehingga penjabaran yang didapat merupakan refleksi dari jawaban mayoritas responden. Emotional branding merupakan strategi pemasaran yang berupaya menghubungkan konsumen dan produk secara emotional. Nilai yang terkandung di dalamnya seperti kenyamanan, ketulusan, menyenangkan, rasa hormat dan selera seseorang yang melibatkan panca indera terkadang belum dapat dijabarkan secara mendalam melalui metode penelitian ini.

\section{Kesimpulan:-}

Berdasarkan hasil dan pembahasan penelitian tentang pengaruh emotional branding terhadap switching intention konsumen rawat inap Rumah Sakit Universitas Muhammadiyah Malang (RS UMM) maka dapat diambil kesimpulan bahwa keseluruhan variabel dalam emotional branding (relationship, sensorial experience, imagination dan vision) bersama-sama berpengaruh secara bermakna terhadap switching intention konsumen rawat inap RS UMM. Artinya semakin besar penerapan emotional branding maka switching intention konsumen rawat inap akan mengalami perubahan.

Secara parsial terdapat pengaruh yang bermakna imagination dan vision terhadap switching intention, sedangkan relationship dan sensorial experience tidak terdapat pengaruh yang bermakna terhadap switching intention konsumen 
rawat inap RS UMM. Hal ini berarti semakin baik imagination dan vision cenderung dapat menurunkan switching intention. Begitu pula dengan relationship, namun penurunan tersebut tidak bermakna. Berbeda dengan sensorial experience, semakin baik penerapannya dapat meningkatkan switching intention, namun peningkatan tersebut tidak bermakna.

\section{DaftarPustaka:-}

1. Bawono A., 2016. Penerapan Aspek Spiritualitas-Religiusitas Dalam Keputusan Berobat Di Rumah Sakit Islam, INFERENSI, 5(1): pp. 19-39.

2. Depkes R. 2005, 'Peraturan Pemerintah Nomor 23 Tentang Pengelolaan Keuangan Badan Layanan Umum', Jakarta.

3. Devina R. dan Andreani F., 2015. Analisa Pengembangan Strategi Emotional branding dalam membangun Loyalitas Pelanggan Garuda Indonesia Airlines, Jurnal Hospitality dan Manajemen Jasa, 1(1): pp. 380-395.

4. Fajar M.I. dan Hasibuan R., 2016. Pengaruh Kualitas Pelayanan Dan Kepuasan Pasien Terhadap Loyalitas Pasien Rawat Jalan Dan Rawat Inap Di Rumah Sakit Embung Fatimah Batam, EQUILIBIRIA, 3(2).

5. Ferrinadewi E., 2008. Merek \& psikologi pelanggan: implikasi pada strategi pemasaran, Edisi Pertama, Cetakan Pertama, Penerbit: Graha Ilmu, Yogyakarta.

6. Gobe M., 2010. Emotional branding, Revised Edition: The New Paradigm for Connecting Brands to People, Skyhorse Publishing, Inc.

7. Grisaffe D.B. dan Nguyen H.P., 2011. Antecedents of emotional attachment to brands, Journal of Business Research, 64(10): pp. 1052-1059.

8. Jatmiko R.D. dan Andharini S.N., 2012. Analisis experiential marketing dan loyalitas pelanggan jasa wisata (Studi pada Taman Rekreasi Sengkaling Malang), Jurnal Manajemen dan Kewirausahaan, 14(2): pp. 128-137.

9. Kapferer J.-N., 2012. The new strategic brand management: Advanced insights and strategic thinking, Kogan page publishers.

10. Kartajaya H., 2007. Hermawan Kartajaya on brand, Mizan Pustaka.

11. Keaveney S.M., 1995. Customer switching behavior in service industries: An exploratory study, The Journal of Marketing: pp. 71-82.

12. Keaveney S.M. dan Parthasarathy M., 2001. Customer switching behavior in online services: An exploratory study of the role of selected attitudinal, behavioral, and demographic factors, Journal of the academy of marketing science, 29(4): pp. 374-390.

13. Kurnia Dewi N., Dimyati M. dan Halim A., 2014. Pengaruh Kualitas Layanan dan Kepuasan Pelanggan Terhadap Switching intention Pengguna Jasa Rumah Kost di Wilayah Kecamatan Sumbersari Jember.

14.Lynch J. dan De Chernatony L., 2004. The power of emotion: Brand communication in business-to-business markets, Journal of Brand management, 11(5): pp. 403-419.

15. McIlroy A. dan Barnett S., 2000. Building customer relationships: do discount cards work?, Managing Service Quality: An International Journal, 10(6): pp. 347-355

16. Meka G.Y. 2011, Analisis Pengaruh Emotional branding terhadap Perilaku Brand Switching Pelanggan pada Pembelian Produk Handphone Merek Nokia (Studi pada Mahasiswa Angkatan 2007 Jurusan Pendidikan Ilmu Pengetahuan Sosial FKIP UNS). Tidak diterbitkan, Universitas Sebelas Maret.

17. RS UMM 2015, Laporan Tahunan RS UMM Tahun 2015, Malang.

18. Sujarweni V.W., 2015. Metodologi penelitian bisnis \& Ekonomi, Pustaka Baru Pers, Yogyakarta.

19. Thomson M., MacInnis D.J. dan Park C.W., 2005. The ties that bind: Measuring the strength of consumers' emotional attachments to brands, Journal of consumer psychology, 15(1): pp.77-91. 